\title{
Triple oxygen isotope analysis of nitrate using the denitrifier method and thermal decomposition of $\mathrm{N}_{2} \mathrm{O}$
}

Supporting Information

Jan Kaiser $^{*, \dagger,}$, Meredith G. Hastings ${ }^{\dagger, \S}$, Benjamin Z. Houlton ${ }^{\dagger, \text {, }}$, Thomas Röckmann ${ }^{\ddagger, \perp}$, Daniel M. Sig$\operatorname{man}^{\dagger}$

* Corresponding author. Current address: University of East Anglia, School of Environmental Sciences, Earlham Road, Norwich, NR4 7TJ, United Kingdom. Email: J.Kaiser@uea.ac.uk. Tel: +44 (1603) 59-3393. Fax: +44 (1603) 59-1327.

$\dagger$ Department of Geosciences, Princeton University, Princeton, New Jersey 08544, USA

* Atmospheric Physics Division, Max Planck Institute for Nuclear Physics, Heidelberg, Germany

$\S$ Current address: Joint Institute for the Study of the Atmosphere and Ocean and Department of Atmospheric Sciences, University of Washington, Seattle, Washington, USA

II Current address: School of Biological Sciences, Stanford University and Carnegie Institution of Washington, Department of Global Ecology, Stanford, California, USA

${ }^{\perp}$ Current address: Institute for Marine and Atmospheric Research Utrecht, Utrecht University, The Netherlands

Abstract. This Supporting Information provides a detailed description of the $\mathrm{O}_{2}$ and $\mathrm{N}_{2} \mathrm{O}$ isotope data reduction procedures applied to the raw molecular ${ }^{33} \delta\left(\mathrm{O}_{2}\right),{ }^{34} \delta\left(\mathrm{O}_{2}\right),{ }^{45} \delta\left(\mathrm{N}_{2} \mathrm{O}\right)$, and ${ }^{46} \delta\left(\mathrm{N}_{2} \mathrm{O}\right)$ values from nitrate samples analyzed by the $\mathrm{N}_{2} \mathrm{O}$ decomposition method in combination with the denitrifier method. Corrections are included for isobaric interferences (e.g., ${ }^{17} \mathrm{O}_{2} /{ }^{16} \mathrm{O}^{18} \mathrm{O},{ }^{14} \mathrm{~N}_{2}{ }^{17} \mathrm{O} /{ }^{15} \mathrm{~N}^{14} \mathrm{~N}^{16} \mathrm{O}$, or ${ }^{15} \mathrm{~N}_{2}{ }^{16} \mathrm{O} /$ ${ }^{14} \mathrm{~N}_{2}{ }^{18} \mathrm{O}$ ). For the purposes of this paper, the atomic $\delta^{17} \mathrm{O}\left(\mathrm{O}_{2}\right)$ and $\delta^{18} \mathrm{O}\left(\mathrm{O}_{2}\right)$ values can be equated with the ${ }^{33} \delta\left(\mathrm{O}_{2}\right)$ and ${ }^{34} \delta\left(\mathrm{O}_{2}\right)$ values measured by gas chromatography/isotope ratio mass spectrometry relative to the working reference gas. We describe a complete and accurate way to compute $\left.\delta^{15} \mathrm{~N}_{(} \mathrm{NO}_{3}^{-}\right)$and $\delta^{18} \mathrm{O}\left(\mathrm{NO}_{3}^{-}\right)$values on international isotope scales from raw ${ }^{45} \delta\left(\mathrm{N}_{2} \mathrm{O}\right)$ and ${ }^{46} \delta\left(\mathrm{N}_{2} \mathrm{O}\right)$ values, taking into account possible ${ }^{17} \mathrm{O}$ anomalies of sample and standard. Further corrections are made for isotope exchange between nitrogen oxy-anions and water during bacterial conversion of nitrate to $\mathrm{N}_{2} \mathrm{O}$ and blanks in the denitrifier technique. The advantages of a logarithmic isotopic scale normalization over a linear scale normalization are discussed. 


\section{$\mathrm{O}_{2}$ isotope data reduction}

In the following, we show how to obtain atomic $\delta^{17} \mathrm{O}\left(\mathrm{O}_{2}\right)$ and $\delta^{18} \mathrm{O}\left(\mathrm{O}_{2}\right)$ values (short: $\delta^{17} \mathrm{O}, \delta^{18} \mathrm{O}$ ) from the molecular raw ${ }^{33} \delta\left(\mathrm{O}_{2}\right)$ and ${ }^{34} \delta\left(\mathrm{O}_{2}\right)$ measurements (short: ${ }^{33} \delta,{ }^{34} \delta$ ) of the mass spectrometer. It will be seen that the atomic $\delta^{17} \mathrm{O}\left(\mathrm{O}_{2}\right)$ and $\delta^{18} \mathrm{O}\left(\mathrm{O}_{2}\right)$ values can be equated with the ${ }^{33} \delta$ and ${ }^{34} \delta$ values, for the purposes of this paper.

The isotope ratio mass spectrometer measures the ion current ratios at $m / \mathrm{z} 32,33$, and 34 , corresponding to the molecular oxygen species ${ }^{16} \mathrm{O}_{2},{ }^{16} \mathrm{O}^{17} \mathrm{O},{ }^{16} \mathrm{O}^{18} \mathrm{O}$ and ${ }^{17} \mathrm{O}_{2}$. The following relations hold between the atomic isotope ratios, ${ }^{17} R$ and ${ }^{18} R$, and the relative isotope enrichments, $\delta^{17} \mathrm{O}$ and $\delta^{18} \mathrm{O}$

$$
\begin{gathered}
{ }^{17} R={ }^{17} R_{\text {ref }}\left(1+\delta^{17} \mathrm{O}\right) \\
{ }^{18} R={ }^{18} R_{\text {ref }}\left(1+\delta^{18} \mathrm{O}\right)
\end{gathered}
$$

and between the molecular and atomic isotope ratios for $\mathrm{O}_{2}$

$$
\begin{aligned}
& { }^{33} R=2{ }^{17} R={ }^{33} R_{\text {ref }}\left(1+{ }^{33} \delta\right)=2{ }^{17} R_{\text {ref }}\left(1+{ }^{33} \delta\right) \\
& { }^{34} R={ }^{17} R^{2}+2{ }^{18} R={ }^{34} R_{\text {ref }}\left(1+{ }^{34} \delta\right)=\left({ }^{17} R_{\text {ref }}^{2}+2{ }^{18} R_{\text {ref }}\right)\left(1+{ }^{34} \delta\right) .
\end{aligned}
$$

The index "ref" refers to the isotope ratio of $\mathrm{O}_{2}$ produced from the nitrate reference sample (e.g., IAEA-NO-3). Thus, we obtain the following $\delta^{17} \mathrm{O}$ and $\delta^{18} \mathrm{O}$ values:

$$
\begin{aligned}
\delta^{17} \mathrm{O} & =\frac{{ }^{17} R}{{ }^{17} R_{\text {ref }}}-1=\frac{{ }^{33} R / 2}{{ }^{33} R_{\text {ref }} / 2}-1 \\
& ={ }^{33} \delta \\
\delta^{18} \mathrm{O} & =\frac{{ }^{18} R}{{ }^{18} R_{\text {ref }}}-1=\frac{{ }^{34} R-{ }^{17} R^{2}}{{ }^{34} R_{\text {ref }}-{ }^{17} R_{\text {ref }}^{2}}-1 \\
& =\frac{\left(2^{18} R_{\text {ref }}+{ }^{17} R_{\text {ref }}^{2}\right)\left(1+{ }^{34} \delta\right)-{ }^{17} R_{\text {ref }}^{2}\left(1+{ }^{33} \delta\right)^{2}}{2^{18} R_{\text {ref }}}-1 \\
& ={ }^{34} \delta+\frac{{ }^{17} R_{\text {ref }}^{2}}{2^{18} R_{\text {ref }}}\left({ }^{34} \delta-2{ }^{33} \delta-{ }^{33} \delta^{2}\right)
\end{aligned}
$$

The $\delta^{17} \mathrm{O}$ value is identical to the raw measured ${ }^{33} \delta$ value; $\delta^{18} \mathrm{O}$ is very close to ${ }^{34} \delta$. The necessary correction is negligibly small, since ${ }^{17} R_{\text {ref }}^{2} /\left(2{ }^{18} R_{\text {ref }}\right) \approx{ }^{17} R_{\text {VSMOW }}^{2} /\left(2^{18} R_{\text {VSMOW }}\right)=(0.0003799)^{2} / 0.0040104=$ $3.6 \cdot 10^{-5}$, where ${ }^{17} R_{\mathrm{VSMOW}}$ and ${ }^{18} R_{\mathrm{VSMOW}}$ are the oxygen isotope ratios of VSMOW [Baertschi, 1976; Li et al., 1988]. The term ${ }^{34} \delta-2{ }^{33} \delta-{ }^{33} \delta^{2}$ is close to $-2 \Delta^{17} \mathrm{O}$, so that even for the largest ${ }^{17} \mathrm{O}$ anomalies of $\Delta^{17} \mathrm{O}$ $=-32 \%$ and $+33 \%$ (at $\delta^{18} \mathrm{O}$ values of $-120 \%$ and $+128 \%$ ) encountered in the present study, the $\delta^{18} \mathrm{O}$ corrections are only $+0.003 \%$ and $-0.003 \%$, which is much smaller than the measurement precision of $0.3 \%$ (see "Precision and absence of memory effects" in section Results and Discussion). We can therefore approximate $\delta^{17} \mathrm{O}$ and $\delta^{18} \mathrm{O}$ by the raw ${ }^{33} \delta$ and ${ }^{34} \delta$ values. 


\section{$\mathrm{N}_{2} \mathrm{O}$ isotope data reduction}

Basic procedures. In the following, we describe a complete and accurate way to compute $\delta^{15} \mathrm{~N}\left(\mathrm{~N}_{2} \mathrm{O}\right)$, $\delta^{17} \mathrm{O}\left(\mathrm{N}_{2} \mathrm{O}\right)$, and $\delta^{18} \mathrm{O}\left(\mathrm{O}_{2}\right)$ values ( short: $\left.\delta^{15} \mathrm{~N}, \delta^{17} \mathrm{O}, \delta^{18} \mathrm{O}\right)$ from raw molecular ${ }^{45} \delta\left(\mathrm{N}_{2} \mathrm{O}\right)$ and ${ }^{46} \delta\left(\mathrm{N}_{2} \mathrm{O}\right)$ values measured by gas chromatography/isotope ratio mass spectrometry relative to the working reference gas. Corrections are included for isobaric interferences (e.g., ${ }^{14} \mathrm{~N}_{2}{ }^{17} \mathrm{O}$ and ${ }^{15} \mathrm{~N}^{14} \mathrm{~N}^{16} \mathrm{O}$, or ${ }^{15} \mathrm{~N}_{2}{ }^{16} \mathrm{O}$ and ${ }^{14} \mathrm{~N}_{2}{ }^{18} \mathrm{O}$ ), $\Delta{ }^{17} \mathrm{O}$ anomalies of sample and standard, isotope exchange between nitrogen oxy-anions and water during bacterial denitrification of nitrate to $\mathrm{N}_{2} \mathrm{O}$ and blanks in the denitrifier technique.

For high-precision gas chromatography/isotope ratio mass spectrometry, it is important that sample and reference material undergo identical treatment in isotope ratio determinations and data reduction ("IT principle" [Werner and Brand, 2001]). As explained by Casciotti et al. [2002], we therefore use a nitrate reference material (IAEA-NO-3), which undergoes the same bacterial denitrification process as the samples, to place our results on international scales (atmospheric $\mathrm{N}_{2}$ for nitrogen isotopes and VSMOW for oxygen isotopes). The volumes of reference material and sample added to the vials containing denitrifiers are adjusted to give the same amount of initial nitrate (e.g., $20 \mathrm{nmol}$ for $\delta^{15} \mathrm{~N} / \delta^{18} \mathrm{O}$ analysis, $50 \mathrm{nmol}$ for $\delta^{17} \mathrm{O} / \delta^{18} \mathrm{O}$ analysis). Thus, we do not use the working reference gas to calculate the isotopic composition of a sample, but rather base our calculations on the assigned $\delta^{15} \mathrm{~N}$ of $4.7 \%$ vs. atmospheric $\mathrm{N}_{2}$ for IAEANO-3 [Böhlke and Coplen, 1995] and a $\delta^{18} \mathrm{O}$ value of $25.6 \%$ vs. VSMOW. The latter value was obtained by on-line carbon combustion and GC/IRMS [Böhlke et al., 2003], which avoids isotope exchange with quartz or glass surfaces [Révész and Böhlke, 2002] that may have led to a previously used lower value of 22.7\% [Révész et al., 1997; Silva et al., 2000]. In principle, the isobaric correction requires knowledge of the absolute isotopic composition of either the working reference gas or the $\mathrm{N}_{2} \mathrm{O}$ produced from IAEANO-3, which would have to be measured independently. However, the influence of variations in either of these two properties is small and negligible for the $\mathrm{N}_{2} \mathrm{O}$ isotope measurement precision achieved to date, as explained in the following two sections.

Correction for isobaric interferences. Similar to the case of $\mathrm{O}_{2}$, molecular isotope ratios of $\mathrm{N}_{2} \mathrm{O}$ are reduced to atomic $\delta$ values from ion currents measured at $m / z 44,45$, and 46 . The following equations describe the relationships between molecular and atomic isotope ratios of $\mathrm{N}_{2} \mathrm{O}$ [Kaiser et al., 2003]:

$$
\begin{aligned}
& { }^{45} R={ }^{15} R_{1}+{ }^{15} R_{2}+{ }^{17} \mathrm{R} \\
& { }^{46} R={ }^{18} R+\left({ }^{15} R_{1}+{ }^{15} R_{2}\right){ }^{17} R+{ }^{15} R_{1}{ }^{15} R_{2},
\end{aligned}
$$

where ${ }^{15} R_{1}$ and ${ }^{15} R_{2}$ stand for the atomic isotope ratios at the terminal and central nitrogen position of the $\mathrm{N}_{2} \mathrm{O}$ molecule. For isotope ratios near natural abundance, we can substitute the average ${ }^{15} R$ for ${ }^{15} R_{1}$ and ${ }^{15} R_{2}$, because the arithmetic average, ${ }^{15} R=\left({ }^{15} R_{1}+{ }^{15} R_{2}\right) / 2$, is close to the geometric average, 
$\sqrt{{ }^{15} R_{1}^{15} R_{2}}$. For example, even for an enrichment of $160 \%$ at the central relative to the terminal nitrogen site, the ${ }^{46} \delta$ value only changes by $0.03 \%$ o due to this approximation, which is one order of magnitude smaller than the $\delta^{18} \mathrm{O}$ reproducibility of the denitrifier method [Casciotti et al., 2002]. Using the arithmetic average ${ }^{15} R$, the above equations can therefore be expressed as

$$
\begin{aligned}
{ }^{45} R & =2{ }^{15} R+{ }^{17} \mathrm{R} \\
{ }^{46} R & \approx{ }^{18} R+2{ }^{15} R{ }^{17} R+{ }^{15} R^{2}
\end{aligned}
$$

With ${ }^{45} \delta={ }^{45} R /{ }^{45} R_{\text {ref }}-1, \delta \delta^{15} \mathrm{~N}={ }^{15} R /{ }^{15} R_{\text {ref }}-1$, and $\delta{ }^{17} \mathrm{O}={ }^{17} R /{ }^{17} R_{\text {ref }}-1$, and $\delta^{18} \mathrm{O}={ }^{18} R /{ }^{18} R_{\text {ref }}-1$, the following relationships between molecular and atomic $\delta$ values follow:

$$
\begin{aligned}
& { }^{45} R_{\text {ref }}{ }^{45} \delta=2{ }^{15} R_{\text {ref }} \delta^{15} \mathrm{~N}+{ }^{17} R_{\text {ref }} \delta^{17} \mathrm{O} \\
& { }^{46} R_{\text {ref }}{ }^{46} \delta \approx \delta^{18} \mathrm{O}{ }^{18} R_{\text {ref }}+2{ }^{15} R_{\text {ref }}{ }^{17} R_{\text {ref }}\left(\delta^{15} \mathrm{~N}+\delta^{17} \mathrm{O}+\delta^{15} \mathrm{~N} \delta^{17} \mathrm{O}\right)+{ }^{15} R_{\text {ref }}^{2}\left(2 \delta^{15} \mathrm{~N}+\delta^{15} \mathrm{~N}^{2}\right),
\end{aligned}
$$

where the isotope ratios with index "ref" correspond to those of $\mathrm{N}_{2} \mathrm{O}$ derived from the nitrate reference material used to put the isotope measurements on international scales (IAEA-NO-3). The $\delta^{17} \mathrm{O}$ value of the sample can be calculated from the $\delta^{18} \mathrm{O}$ value and the measured oxygen isotope anomaly:

$$
\delta^{17} \mathrm{O}=\left(1+\Delta^{17} \mathrm{O}\right)\left(1+\delta^{18} \mathrm{O}\right)^{0.5279}-1
$$

The $\Delta^{17} \mathrm{O}$ value here is the normalized result from the $\mathrm{N}_{2} \mathrm{O}$ decomposition method, prior to blank and exchange correction of the conversion of nitrate to $\mathrm{N}_{2} \mathrm{O}$ by the denitrifier culture (see below).

The above equations for ${ }^{45} R_{\text {ref }}{ }^{45} \delta$ and ${ }^{46} R_{\text {ref }}{ }^{46} \delta$ can be solved iteratively for $\delta^{15} \mathrm{~N}$ and $\delta^{18} \mathrm{O}$ of the sample, using the measured ${ }^{45} \delta$ and ${ }^{46} \delta$ of the sample relative to the reference material, IAEA-NO-3. The absolute isotope ratios of IAEA-NO-3 were calculated from ${ }^{15} R\left(\right.$ air- $\left.\mathrm{N}_{2}\right)=0.0036782$ [De Bièvre et al., 1996] and ${ }^{17} R($ VSMOW $)=0.0003799$ [Li et al., 1988], ${ }^{18} R($ VSMOW $)=0.0020052$ [Baertschi, 1976], $\delta^{15} \mathrm{~N}($ IAEA-NO-3 $)=4.7 \% o, \delta^{18} \mathrm{O}($ IAEA-NO-3 $)=25.6 \%$ and $\delta^{17} \mathrm{O}($ IAEA-NO-3 $)=13.2 \%$ [Böhlke et al. 2003]. These $\delta^{17} \mathrm{O}$ and $\delta^{18} \mathrm{O}$ values for IAEA-NO-3 correspond to a $\Delta^{17} \mathrm{O}$ value of $-0.25 \%$. The isotope ratio of $\mathrm{N}_{2} \mathrm{O}$ produced from IAEA-NO-3 varies depending on size of the blank, oxygen isotope effect during denitrification, degree of isotope exchange with water and isotopic composition of the sample water [Casciotti et al., 2002]. Therefore, the equations describing blank and exchange correction have to be solved simultaneously with the above equations, which requires another iterative calculation. Moreover, the oxygen isotope effect during denitrification is generally not known and has to be measured independently.

We therefore prefer an equivalent approach based on the isotopic composition of the $\mathrm{N}_{2} \mathrm{O}$ working reference gas tank. The latter quantity is not generally known either, but applying this second approach is simpler as it does not require an iterative solution to the blank and exchange correction. We will therefore base our derivation in the following on the second approach. However, note that both approaches are 
nearly equivalent and the uncertainty introduced into the final $\delta^{15} \mathrm{~N}$ and $\delta^{18} \mathrm{O}$ values of the nitrate sample by either the oxygen isotope effect during denitrification or the isotopic composition of the $\mathrm{N}_{2} \mathrm{O}$ working reference gas tank is small and negligible $\left(<0.08 \%\right.$ in the final $\delta^{15} \mathrm{~N}$ value of the nitrate sample for a $40 \%$ o uncertainty in the oxygen isotope effect; $<0.05 \%$ in the final $\delta^{15} \mathrm{~N}$ value for a uncertainty of $20 \%$ / $40 \%$ o in $\delta^{15} \mathrm{~N} / \delta^{18} \mathrm{O}$ of the $\mathrm{N}_{2} \mathrm{O}$ working reference gas tank; <0.02\% in the final $\delta^{18} \mathrm{O}$ value for all cases).

Blank and exchange correction of the oxygen isotope ratios. The blank and exchange correction of the oxygen isotope ratios is treated here first. The simpler case for nitrogen isotope ratios that only require a blank correction is then derived by analogy.

The composition of $\mathrm{N}_{2} \mathrm{O}$ formed in the denitrifier method can be understood in terms of an amount of substance balance [Casciotti et al., 2002], $n=n_{\text {sample }}+n_{\text {blank, }}$ where indices "sample" and "blank" stand for $\mathrm{N}_{2} \mathrm{O}$ formed from sample nitrate and the $\mathrm{N}_{2} \mathrm{O}$ blank of the method. Denoting the blank fraction, $n_{\text {blank }} /$

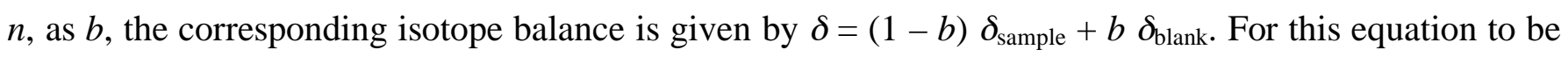
exact, we require that $n_{\text {blank }}$ and $n$ refer to the amount of $\mathrm{N}_{2}{ }^{16} \mathrm{O}$ in the case of oxygen isotope ratios; however, for isotope ratios near natural abundance, $\mathrm{N}_{2}{ }^{16} \mathrm{O}$ is nearly equal to $\mathrm{N}_{2} \mathrm{O}$, since $n\left(\mathrm{~N}_{2} \mathrm{O}\right)=\left(1+{ }^{17} R+\right.$ $\left.{ }^{18} R\right) n\left(\mathrm{~N}_{2}{ }^{16} \mathrm{O}\right)$, and ${ }^{17} R,{ }^{18} R<<1$. Essentially the same argument applies for nitrogen isotope ratios.

The isotopic composition of the $\mathrm{N}_{2} \mathrm{O}$ product from bacterial denitrification is determined by the isotope ratio of the sample nitrate, those of the sample and medium water, the degree of isotope exchange and the associated isotope effects. Designating the fraction of ${ }^{16} \mathrm{O}$ atoms from water as $x$, the fractionation factor associated with conversion of nitrate to $\mathrm{N}_{2} \mathrm{O}$ as $\alpha_{\mathrm{N}}$, and the fractionation factor for conversion of the nitrogen oxide intermediate exchanging isotopes with water as $\alpha_{\mathrm{W}}$, we have the following complete isotope balance for the product $\mathrm{N}_{2} \mathrm{O}$ :

$$
\begin{aligned}
1+\delta_{\text {sample }}^{\mathrm{VSMOW}}\left(\mathrm{N}_{2} \mathrm{O}\right)= & \left(1-b_{\text {sample }}\right)\left\{(1-x) \alpha_{\mathrm{N}}\left[1+\delta_{\text {sample }}^{\mathrm{VSMOW}}\left(\mathrm{NO}_{3}^{-}\right)\right]+x \alpha_{\mathrm{W}}\left[1+\delta_{\text {sample }}^{\mathrm{VSMOW}}\left(\mathrm{H}_{2} \mathrm{O}\right)\right]\right\} \\
& +b_{\text {sample }}\left[1+\delta_{\text {blank }}^{\mathrm{VSMOW}}\left(\mathrm{N}_{2} \mathrm{O}\right)\right]
\end{aligned}
$$

The blank fraction $b$ and the degree of isotope exchange $x$ are strictly defined in terms of the $\mathrm{N}_{2}{ }^{16} \mathrm{O}$ species, but can be approximated by the total amount of $\mathrm{N}_{2} \mathrm{O}$ for isotope ratios near natural abundance (see above). Subscript indices refer to the corresponding specimen. Superscript indices designate the reference material relative to which the corresponding $\delta$ values are expressed, VSMOW in the present case. However, in practice, the isotope ratio of the $\mathrm{N}_{2} \mathrm{O}$ product is measured relative to the $\mathrm{N}_{2} \mathrm{O}$ working reference gas tank of the mass spectrometer (index "tank"). As noted above, we therefore use a nitrate reference material (index "ref") to put the measured $\delta$ values on international scales. Using Equation $\mathrm{S} 1$, the enrichment of the sample nitrate relative to the nitrate reference material is given by 
S2)

$$
\begin{aligned}
\delta_{\text {sample }}^{\text {ref }}\left(\mathrm{NO}_{3}^{-}\right) & =\frac{1+\delta_{\text {sample }}^{\text {tank }}\left(\mathrm{NO}_{3}^{-}\right)}{1+\delta_{\text {ref }}^{\text {tank }}\left(\mathrm{NO}_{3}^{-}\right)}-1 \\
& =\frac{1-b_{\text {ref }}}{1-b_{\text {sample }}} \frac{1+\delta_{\text {sample }}^{\text {tank }}\left(\mathrm{N}_{2} \mathrm{O}\right)-b_{\text {sample }}\left[1+\delta_{\text {blank }}^{\text {tank }}\left(\mathrm{N}_{2} \mathrm{O}\right)\right]-x\left(1-b_{\text {sample }}\right) \alpha_{\mathrm{w}}\left[1+\delta_{\text {sample }}^{\text {tank }}\left(\mathrm{H}_{2} \mathrm{O}\right)\right]}{1+\delta_{\text {ref }}^{\text {tank }}\left(\mathrm{N}_{2} \mathrm{O}\right)-b_{\text {ref }}\left[1+\delta_{\text {blank }}^{\text {tank }}\left(\mathrm{N}_{2} \mathrm{O}\right)\right]-x\left(1-b_{\text {ref }}\right) \alpha_{\mathrm{w}}\left[1+\delta_{\text {ref }}^{\text {tank }}\left(\mathrm{H}_{2} \mathrm{O}\right)\right]}-1
\end{aligned}
$$

Note that $\delta_{\text {sample }}^{\text {ref }}\left(\mathrm{NO}_{3}^{-}\right)$is independent of the fractionation factor $\alpha_{\mathrm{N}}$. The blank fractions $b$ and $b_{\text {ref }}$ can be calculated from the integrated peak areas; $\delta_{\text {sample }}^{\text {tank }}\left(\mathrm{N}_{2} \mathrm{O}\right), \delta_{\mathrm{ref}}^{\mathrm{tank}}\left(\mathrm{N}_{2} \mathrm{O}\right)$, and $\delta_{\text {blank }}^{\mathrm{tank}}\left(\mathrm{N}_{2} \mathrm{O}\right)$ are measured directly. The degree of isotope exchange $x$ and the ${ }^{17} \mathrm{O} /{ }^{16} \mathrm{O}$ and ${ }^{18} \mathrm{O} /{ }^{16} \mathrm{O}$ isotope ratios of the mixture of sample and medium water relative to those of the $\mathrm{N}_{2} \mathrm{O}$ working reference gas tank, i.e. $\delta_{\text {sample }}^{\mathrm{tank}}\left(\mathrm{H}_{2} \mathrm{O}\right)$ and $\delta_{\mathrm{ref}}^{\mathrm{tank}}\left(\mathrm{H}_{2} \mathrm{O}\right)$, have to be established independently, as explained in the following.

First, consider $\delta_{\mathrm{sample}}^{\mathrm{tank}}\left(\mathrm{H}_{2} \mathrm{O}\right)$ and $\delta_{\mathrm{ref}}^{\mathrm{tank}}\left(\mathrm{H}_{2} \mathrm{O}\right)$. These $\delta$ values can be expressed relative VSMOW as

S3) $1+\delta_{\text {sample }}^{\text {tank }}\left(\mathrm{H}_{2} \mathrm{O}\right)=\frac{1+\delta_{\text {sample }}^{\text {VSMOW }}\left(\mathrm{H}_{2} \mathrm{O}\right)}{1+\delta_{\text {tank }}^{\text {VSMOW }}\left(\mathrm{N}_{2} \mathrm{O}\right)}$

$\delta^{\mathrm{VSMOW}}\left(\mathrm{H}_{2} \mathrm{O}\right)$ is the relative isotopic enrichment of the mixture of medium and sample water with respect to VSMOW. $\delta_{\text {tank }}^{\mathrm{VSMOW}}\left(\mathrm{N}_{2} \mathrm{O}\right)$ is the isotopic enrichment of the machine reference $\mathrm{N}_{2} \mathrm{O}$ tank with respect to VSMOW. Substituting Equation S3 into Equation S2 and defining a modified degree of isotope exchange $x^{\prime}$ as

$$
x^{\prime} \equiv \frac{x \alpha_{\mathrm{W}}}{1+\delta_{\text {tank }}^{\mathrm{VSMOW}}\left(\mathrm{N}_{2} \mathrm{O}\right)}
$$

one obtains

$\mathrm{S} 4) \delta_{\text {sample }}^{\text {ref }}\left(\mathrm{NO}_{3}^{-}\right)=\frac{1-b_{\text {ref }}}{1-b_{\text {sample }}} \frac{1+\delta_{\text {sample }}^{\text {tank }}\left(\mathrm{N}_{2} \mathrm{O}\right)-b_{\text {sample }}\left[1+\delta_{\text {blank }}^{\text {tank }}\left(\mathrm{N}_{2} \mathrm{O}\right)\right]-x^{\prime}\left(1-b_{\text {sample }}\right)\left[1+\delta_{\text {sample }}^{\text {VSMOW }}\left(\mathrm{H}_{2} \mathrm{O}\right)\right]}{1+\delta_{\text {ref }}^{\text {tank }}\left(\mathrm{N}_{2} \mathrm{O}\right)-b_{\text {ref }}\left[1+\delta_{\text {blank }}^{\text {tank }}\left(\mathrm{N}_{2} \mathrm{O}\right)\right]-x^{\prime}\left(1-b_{\text {ref }}\right)\left[1+\delta_{\text {ref }}^{\mathrm{VSMOW}}\left(\mathrm{H}_{2} \mathrm{O}\right)\right]}-1$

It remains to determine the degree of isotope exchange $x$ (or, equivalently, $x^{\prime}$ ). As described previously [Casciotti et al., 2002], we measure it by spiking a solution of IAEA-NO-3 reference material with ${ }^{18} \mathrm{O}-$ enriched water. Comparing $\delta^{\text {tank }}\left(\mathrm{N}_{2} \mathrm{O}\right)$ values of the spiked ("spike") and unspiked ("ref") reference nitrate sample, we can then calculate $x$, based on Equation S1 (changing the reference from VSMOW to tank):

$$
\begin{aligned}
x \alpha_{\mathrm{w}}\left[\delta_{\text {spike }}^{\mathrm{tank}}\left(\mathrm{H}_{2} \mathrm{O}\right)-\delta_{\text {ref }}^{\mathrm{tank}}\left(\mathrm{H}_{2} \mathrm{O}\right)\right]= & \frac{1+\delta_{\text {spike }}^{\mathrm{tank}}\left(\mathrm{N}_{2} \mathrm{O}\right)-b_{\text {spike }}\left[1+\delta_{\text {blank }}^{\mathrm{tank}}\left(\mathrm{N}_{2} \mathrm{O}\right)\right]}{1-b_{\text {spike }}} \\
& -\frac{1+\delta_{\text {ref }}^{\text {tank }}\left(\mathrm{N}_{2} \mathrm{O}\right)-b_{\text {ref }}\left[1+\delta_{\text {blank }}^{\mathrm{tank}}\left(\mathrm{N}_{2} \mathrm{O}\right)\right]}{1-b_{\text {ref }}} \\
= & \frac{\delta_{\text {spike }}^{\mathrm{tank}}\left(\mathrm{N}_{2} \mathrm{O}\right)-\delta_{\text {blank }}^{\mathrm{tank}}\left(\mathrm{N}_{2} \mathrm{O}\right)}{1-b_{\text {spike }}}-\frac{\delta_{\text {ref }}^{\mathrm{tank}}\left(\mathrm{N}_{2} \mathrm{O}\right)-\delta_{\text {blank }}^{\mathrm{tank}}\left(\mathrm{N}_{2} \mathrm{O}\right)}{1-b_{\text {ref }}}
\end{aligned}
$$

Using the definition of $x^{\prime}$ and equations $\mathrm{S} 3$, this can be re-written as 


$$
x^{\prime}\left[\delta_{\text {spike }}^{\text {VSMOW }}\left(\mathrm{H}_{2} \mathrm{O}\right)-\delta_{\text {ref }}^{\text {VSMOW }}\left(\mathrm{H}_{2} \mathrm{O}\right)\right]=\frac{\delta_{\text {spike }}^{\text {tank }}\left(\mathrm{N}_{2} \mathrm{O}\right)-\delta_{\text {blank }}^{\text {tank }}\left(\mathrm{N}_{2} \mathrm{O}\right)}{1-b_{\text {spike }}}-\frac{\delta_{\text {ref }}^{\text {tank }}\left(\mathrm{N}_{2} \mathrm{O}\right)-\delta_{\text {blank }}^{\text {tank }}\left(\mathrm{N}_{2} \mathrm{O}\right)}{1-b_{\text {ref }}}
$$

If the amount of nitrate in both spiked and unspiked reference nitrate sample are the same, then $b_{\text {spike }}=$ $b_{\text {ref }}$, and

$$
x^{\prime}=\frac{1}{1-b_{\text {spike }}} \frac{\delta_{\text {spike }}^{\text {tank }}\left(\mathrm{N}_{2} \mathrm{O}\right)-\delta_{\text {ref }}^{\text {tank }}\left(\mathrm{N}_{2} \mathrm{O}\right)}{\delta_{\text {spike }}^{\text {VSMOW }}\left(\mathrm{H}_{2} \mathrm{O}\right)-\delta_{\text {ref }}^{\text {VSMOW }}\left(\mathrm{H}_{2} \mathrm{O}\right)}
$$

Substituting the relation for $x^{\prime}$ obtained here into Equation S4 allows for determination of the isotopic composition of the sample, $\delta_{\text {sample }}^{\text {ref }}\left(\mathrm{NO}_{3}^{-}\right)$, without knowing the isotopic composition of the $\mathrm{N}_{2} \mathrm{O}$ reference tank and the fractionation factor for conversion of the nitrogen oxide intermediate exchanging isotopes with water $\left(\alpha_{\mathrm{W}}\right)$, provided $\alpha_{\mathrm{W}}$ is always the same. This disregards the influence of the isotopic composition of the $\mathrm{N}_{2} \mathrm{O}$ reference tank on the isobaric correction, but this effect is negligible as discussed above. With $b_{\text {ref }}=b_{\text {spike }}=b_{\text {sample, }}$ we obtain

$$
\text { S5) } \delta_{\text {sample }}^{\text {ref }}\left(\mathrm{NO}_{3}^{-}\right)=\frac{\delta_{\text {sample }}^{\text {tank }}\left(\mathrm{N}_{2} \mathrm{O}\right)-\delta_{\text {ref }}^{\text {tank }}\left(\mathrm{N}_{2} \mathrm{O}\right)-\delta_{\text {sample }}^{\text {ref }}\left(\mathrm{H}_{2} \mathrm{O}\right)\left[\delta_{\text {spike }}^{\text {tank }}\left(\mathrm{N}_{2} \mathrm{O}\right)-\delta_{\text {ref }}^{\text {tank }}\left(\mathrm{N}_{2} \mathrm{O}\right)\right] / \delta_{\text {spike }}^{\text {ref }}\left(\mathrm{H}_{2} \mathrm{O}\right)}{1+\delta_{\text {ref }}^{\text {tank }}\left(\mathrm{N}_{2} \mathrm{O}\right)-b_{\text {sample }}\left[1+\delta_{\text {blank }}^{\text {tank }}\left(\mathrm{N}_{2} \mathrm{O}\right)\right]-\left[\delta_{\text {spike }}^{\text {tank }}\left(\mathrm{N}_{2} \mathrm{O}\right)-\delta_{\text {ref }}^{\text {tank }}\left(\mathrm{N}_{2} \mathrm{O}\right)\right] / \delta_{\text {spike }}^{\text {ref }}\left(\mathrm{H}_{2} \mathrm{O}\right)}
$$

Note that $\delta_{\text {sample }}^{\text {ref }}\left(\mathrm{H}_{2} \mathrm{O}\right)$ and $\delta_{\text {spike }}^{\text {ref }}\left(\mathrm{H}_{2} \mathrm{O}\right)$ refer to the isotopic composition of the water in the sample and the spiked reference nitrate sample (including medium water), respectively, relative to that of the water in the reference sample.

For completeness, we note that basing the isobaric correction on the $\delta$ values relative to $\mathrm{N}_{2} \mathrm{O}$ produced from the nitrate reference material IAEA-NO-3, Equation S5 takes the following form

S6) $\delta_{\text {sample }}^{\text {ref }}\left(\mathrm{NO}_{3}^{-}\right)=\frac{\delta_{\text {sample }}^{\text {ref }}\left(\mathrm{N}_{2} \mathrm{O}\right)-\delta_{\text {sample }}^{\text {ref }}\left(\mathrm{H}_{2} \mathrm{O}\right) \delta_{\text {spike }}^{\text {ref }}\left(\mathrm{N}_{2} \mathrm{O}\right) / \delta_{\text {spike }}^{\text {ref }}\left(\mathrm{H}_{2} \mathrm{O}\right)}{1-b\left[1+\delta_{\text {blank }}^{\text {ref }}\left(\mathrm{N}_{2} \mathrm{O}\right)\right]-\delta_{\text {spike }}^{\text {ref }}\left(\mathrm{N}_{2} \mathrm{O}\right) / \delta_{\text {spike }}^{\text {ref }}\left(\mathrm{H}_{2} \mathrm{O}\right)}$

Blank correction of the nitrogen isotope ratio. In analogy to the oxygen isotope correction given in Equation S4, the blank correction of the nitrogen isotope ratio is calculated as

S7) $\delta^{15} \mathrm{~N}_{\text {sample }}^{\text {ref }}\left(\mathrm{NO}_{3}^{-}\right)=\frac{1-b_{\text {ref }}}{1-b_{\text {sample }}} \frac{1+\delta^{15} \mathrm{~N}_{\text {sample }}^{\text {tank }}\left(\mathrm{N}_{2} \mathrm{O}\right)-b_{\text {sample }}\left[1+\delta^{15} \mathrm{~N}_{\text {blank }}^{\text {tank }}\left(\mathrm{N}_{2} \mathrm{O}\right)\right]}{1+\delta^{15} \mathrm{~N}_{\text {ref }}^{\mathrm{tank}}\left(\mathrm{N}_{2} \mathrm{O}\right)-b_{\text {ref }}\left[1+\delta^{15} \mathrm{~N}_{\text {blank }}^{\mathrm{tank}}\left(\mathrm{N}_{2} \mathrm{O}\right)\right]}-1$

Assuming $b_{\text {ref }}=b_{\text {sample, }}$ this simplifies to

S8) $\delta^{15} \mathrm{~N}_{\text {sample }}^{\text {ref }}\left(\mathrm{NO}_{3}^{-}\right)=\frac{\delta^{15} \mathrm{~N}^{\mathrm{tank}}\left(\mathrm{N}_{2} \mathrm{O}\right)-\delta^{15} \mathrm{~N}_{\text {ref }}^{\mathrm{tank}}\left(\mathrm{N}_{2} \mathrm{O}\right)}{1+\delta^{15} \mathrm{~N}_{\text {ref }}^{\mathrm{tank}}\left(\mathrm{N}_{2} \mathrm{O}\right)-b_{\text {sample }}\left[1+\delta^{15} \mathrm{~N}_{\text {blank }}^{\mathrm{tank}}\left(\mathrm{N}_{2} \mathrm{O}\right)\right]}$

and furthermore, had we based the isobaric correction on $\mathrm{N}_{2} \mathrm{O}$ produced from IAEA-NO-3,

S9) $\delta^{15} \mathrm{~N}_{\text {sample }}^{\text {ref }}\left(\mathrm{NO}_{3}^{-}\right)=\frac{\delta^{15} \mathrm{~N}_{\text {sample }}^{\text {ref }}\left(\mathrm{N}_{2} \mathrm{O}\right)}{1-b_{\text {sample }}\left[1+\delta^{15} \mathrm{~N}_{\text {blank }}^{\text {tank }}\left(\mathrm{N}_{2} \mathrm{O}\right)\right]}$ 


\section{Isotopic scale normalization}

In the following, we explain why we prefer a logarithmic isotope scale normalization (as defined in the main text of the paper) over the linear one often found in the literature, e.g., Coplen et al. [1988].

The scale normalization is used here to bring the $\mathrm{O}_{2}$ isotope measurements to the same scale as the $\mathrm{N}_{2} \mathrm{O}$ isotope measurements. The logarithmic normalization defined as Equation 2 in the main text is repeated here

$$
1+{ }^{\text {normalized }} \delta_{\text {sample }}^{\text {USGS } 34}\left(\mathrm{O}_{2}\right)=\left[1+{ }^{\text {measured }} \delta_{\text {sample }}^{\text {USGS-34 }}\left(\mathrm{O}_{2}\right)\right]^{\lambda}
$$

2)

$$
\text { with } 1+{ }^{\text {measured }} \delta_{\text {USGS-35 }}^{\text {USGS-34 }}\left(\mathrm{N}_{2} \mathrm{O}\right)=\left[1+{ }^{\text {measured }} \delta_{\text {USGS-35 }}^{\text {USGS-34 }}\left(\mathrm{O}_{2}\right)\right]^{\lambda} \text {, i.e., } \lambda=\frac{\ln \left[1+{ }^{\text {measured }} \delta_{\mathrm{USGS}-35}^{\text {USGS-34 }}\left(\mathrm{N}_{2} \mathrm{O}\right)\right]}{\ln \left[1+{ }^{\text {measured }} \delta_{\mathrm{USGS}-35}^{\text {USGS-34 }}\left(\mathrm{O}_{2}\right)\right]}
$$

It can be compared to the "linear" scale normalization, which, in the present case, would be defined as

$$
{ }^{\text {normalized }} \delta_{\text {sample }}^{\text {USGS-34 }}\left(\mathrm{O}_{2}\right)=\lambda^{\prime} \text { measured } \delta_{\text {sample }}^{\text {USGS-34 }}\left(\mathrm{O}_{2}\right)
$$

S10)

$$
\text { with }{ }^{\text {measured }} \delta_{\mathrm{USGS}-35}^{\mathrm{USGS}-34}\left(\mathrm{~N}_{2} \mathrm{O}\right)=\lambda^{\prime} \text { measured } \delta_{\mathrm{USGS}-35}^{\mathrm{USGS}-34}\left(\mathrm{O}_{2}\right) \text {, i.e., } \lambda^{\prime}=\frac{{ }_{\text {measured }}^{\text {mSGS-35 }} \delta_{\mathrm{USG}-34}^{\mathrm{USGS}-34}\left(\mathrm{O}_{2}\right)}{\left.\mathrm{N}_{2} \mathrm{O}\right)}
$$

Table S-1 illustrates the differences between both normalizations. Given are three samples (depleted, enriched and intermediate) with hypothetical measured $\delta$ values of $-120.00 \%$ o, $+111.11 \%$, and $-50.00 \%$ o with respect to a reference. The $\delta$ values of the depleted and the enriched samples are assumed to correspond to the same degree of depletion of the depleted sample as the degree of enrichment of the enriched sample. The absolute magnitudes of the $\delta$ values are not the same because of the non-additivity of the $\delta$ scale, but the reader can quickly verify this assumption by comparing the $\delta_{\mathrm{X}}^{\mathrm{ref}}\left(\mathrm{O}_{2}\right)$ in the second column and the $\delta_{\mathrm{ref}}^{\mathrm{X}}\left(\mathrm{O}_{2}\right)$ in the third column of Table $\mathrm{S}-1$. The hypothetical measured values are then normalized to a $\delta$ values of $-120.00 \%$ for the depleted sample, using the linear (Equation S10) and the logarithmic normalizations (Equation 2). Table S-1 illustrates that the linear normalization is not scale-invariant; rather, its magnitude depends on the position of the sample on the scale: Even though the $\delta_{\mathrm{X}}^{\text {ref }}\left(\mathrm{O}_{2}\right)$ value of the enriched sample relative to the reference $(111.11 \%$ o $)$ is the same as the $\delta_{\text {ref }}^{\mathrm{X}}\left(\mathrm{O}_{2}\right)$ value of the reference relative to the depleted sample $(111.11 \%$ o), they not have the same linearly normalized $\delta$ value s $(133.33 \%$ o as opposed to $136.36 \%$ ).

In contrast, as the last two columns of Table S-1 show, the equality of the relative enrichments between enriched sample and reference as well as reference and depleted sample are preserved by the logarithmic normalization.

Finally, the intermediate sample (which might be considered more realistic for environmentally relevant $\delta^{18} \mathrm{O}$ values) in Table S-1 illustrates the potential difference in the normalized $\delta$ value introduced by 
the two normalization schemes (63.83\%o vs. 64.21\%o). With the present measurement precision of about $0.3 \%$ for $\delta^{18} \mathrm{O}$, this may not be relevant, but in view of future improvements and the small computational expense of the logarithmic normalization, we prefer the logarithmic over the linear normalization. 


\section{References}

Baertschi, P. (1976), Absolute ${ }^{18} \mathrm{O}$ content of standard mean ocean water, Earth Planet. Sci. Lett., 31, 341-344.

Böhlke, J. K. and T. B. Coplen (1995), Interlaboratory comparison of reference materials for nitrogenisotope-ratio measurements, in Reference materials and intercomparison materials for stable isotopes of light elements, edited by IAEA, pp. 51-66, International Atomic Energy Agency, Vienna.

Böhlke, J. K., S. J. Mroczkowski, and T. B. Coplen (2003), Oxygen isotopes in nitrate: new reference materials for ${ }^{18} \mathrm{O}:{ }^{17} \mathrm{O}:{ }^{16} \mathrm{O}$ measurements and observations on nitrate-water equilibration, Rapid Commun. Mass Spectrom., 17, 1835-1846.

Casciotti, K. L., D. M. Sigman, M. G. Hastings, J. K. Böhlke, and A. Hilkert (2002), Measurement of the oxygen isotopic composition of nitrate in seawater and freshwater using the denitrifier method, Anal. Chem., 74, 4905-4912, doi:10.1021/ac020113w.

Coplen, T. B. (1988), Normalization of oxygen and hydrogen isotope data, Chem. Geol., 72, 293-297.

De Bièvre, P., S. Valkiers, H. S. Peiser, P. D. P. Taylor, and P. Hansen (1996), Mass-spectrometric methods for determining isotopic composition and molar mass traceable to the SI, exemplified by improved values for nitrogen, Metrologia, 33, 447-455.

Kaiser, J., T. Röckmann, and C. A. M. Brenninkmeijer (2003), Complete and accurate massspectrometric isotope analysis of tropospheric nitrous oxide, J. Geophys. Res., 108, 4476, doi:10.1029/2003JD003613.

Li, W.-J., B. Ni, D. Jin, and T.-L. Chang (1988), Measurement of the absolute abundance of oxygen17 in V-SMOW, Chin. Sci. Bull., 33, 1610-1613.

Révész, K., J. K. Böhlke, and T. Yoshinari (1997), Determination of $\delta^{18} \mathrm{O}$ and $\delta^{15} \mathrm{~N}$ in nitrate, Anal. Chem., 69, 4375-4380.

Révész, K. and J.-K. Böhlke (2002), Comparison of $\delta^{18} \mathrm{O}$ measurements in nitrate by different combustion techniques, Anal. Chem., 74, 5410-5413, doi: 10.1021/ac025854b.

Silva, S. R., C. Kendall, D. H. Wilkison, C. C. Y. C. Chang, and R. J. Avanzino (2000), A new method for collection of nitrate from fresh water and analysis for its nitrogen and oxygen isotope ratios, J. Hydrol., 28, 22-36.

Werner, R. A. and W. A. Brand (2001), Referencing strategies and techniques in stable isotope ratio analysis, Rapid Commun. Mass Spectrom., 15, 501-519. 
Table S-1. Scale normalization of (hypothetical) measured $\delta\left(\mathrm{O}_{2}\right)$ values.

\begin{tabular}{lrrrrrr} 
& \multicolumn{2}{c}{ measured } & \multicolumn{2}{c}{ linearly normalized } & \multicolumn{2}{c}{$\begin{array}{c}\text { logarithmically } \\
\text { normalized }^{\mathrm{b}}\end{array}$} \\
$\begin{array}{l}\delta \text { value }^{\mathrm{a}} \\
\text { reference }\end{array}$ & $\delta_{\mathrm{X}}^{\mathrm{ref}}\left(\mathrm{O}_{2}\right) / \% 0$ & $\delta_{\mathrm{ref}}^{\mathrm{X}}\left(\mathrm{O}_{2}\right) / \% 0$ & $\delta_{\mathrm{X}}^{\mathrm{ref}}\left(\mathrm{O}_{2}\right) / \% 0$ & $\delta_{\mathrm{ref}}^{\mathrm{X}}\left(\mathrm{O}_{2}\right) / \% 0$ & $\delta_{\mathrm{X}}^{\mathrm{ref}} /\left(\mathrm{O}_{2}\right) \%$ & $\delta_{\text {ref }}^{\mathrm{X}}\left(\mathrm{O}_{2}\right) / \% 0$ \\
intermediate & -50.00 & 0.00 & 0.00 & 0.00 & 0.00 & 0.00 \\
depleted & -100.00 & 111.11 & -120.00 & 136.36 & -120.00 & 136.36 \\
enriched & 111.11 & -100.00 & 133.33 & -117.65 & 136.36 & -120.00
\end{tabular}

\footnotetext{
${ }^{\text {a }}$ The true $\delta_{\text {depleted }}^{\text {ref }}\left(\mathrm{O}_{2}\right)$ is assumed to be $-120 \%$. The values for the intermediate and the enriched samples are normalized based on this assumption.

${ }^{\mathrm{b}}$ Calculated in analogy to Equation 2.

${ }^{\mathrm{c}}$ Calculated in analogy to Equation 3.
} 